\title{
Evolution of New Approaches in Pedagogy and STEM with Inquiry-Based Learning and Post-Pandemic Scenarios
}

\author{
Csaba Deák ${ }^{1,2, *}$, Baibhaw Kumar ${ }^{3, *}\left(\mathbb{D}\right.$, István Szabó ${ }^{4}$, Gábor Nagy ${ }^{5}$ and Szabolcs Szentesi ${ }^{5}$ \\ 1 Institute for the Development of Enterprises, Corvinus University of Budapest, 1093 Budapest, Hungary \\ 2 Faculty of Material Science and Engineering, University of Miskolc, 3515 Miskolc, Hungary \\ 3 Institute of Energy Engineering and Chemical Machinery, University of Miskolc, 3515 Miskolc, Hungary \\ 4 Faculty of Business and Economics, University of Pannonia, 8200 Veszprém, Hungary; \\ istvan.szabo@nkfih.gov.hu \\ 5 Institute of Logistics, University of Miskolc, 3515 Miskolc, Hungary; altnagy@uni-miskolc.hu (G.N.); \\ altszabi@uni-miskolc.hu (S.S.) \\ * Correspondence: deak.csaba@uni-miskolc.hu (C.D.); vegybk@uni-miskolc.hu (B.K.)
}

check for updates

Citation: Deák, C.; Kumar, B.; Szabó, I.; Nagy, G.; Szentesi, S. Evolution of New Approaches in Pedagogy and STEM with Inquiry-Based Learning and Post-Pandemic Scenarios. Educ. Sci. 2021, 11, 319. https://doi.org/ 10.3390/educsci11070319

Academic Editor: Ileana Maria Greca

Received: 30 April 2021

Accepted: 23 June 2021

Published: 26 June 2021

Publisher's Note: MDPI stays neutral with regard to jurisdictional claims in published maps and institutional affiliations.

Copyright: (c) 2021 by the authors. Licensee MDPI, Basel, Switzerland. This article is an open access article distributed under the terms and conditions of the Creative Commons Attribution (CC BY) license (https:// creativecommons.org/licenses/by/ $4.0 /)$.

\begin{abstract}
In the last ten years, pedagogy has been evolving rapidly in terms of teaching approaches. This study is an attempt to analyze the recently developed novel pedagogy models. STEM integration and classroom engagement are primary approaches in pedagogy in recent times. The article aims to provide educators with some analytical tools to complement the modernization of STEM pedagogy. Integration flow and skill-set balancing, along with matrix analysis, are projected to be efficient solutions for evolved pedagogy. A novel PESTLE model is framed for tackling the changes in pedagogies during pandemics and emergencies. Inquiry-based learning can foster and accelerate the cause of integrating subjects in STEM pedagogy. In addition, the article discusses the post-pandemic scenario of pedagogy in the education system as a whole.
\end{abstract}

Keywords: pedagogy; STEM; E-learning; inquiry-based-learning; pandemic

\section{Introduction}

An intelligible and radical approach to science, technology, engineering, and mathematics (STEM) education calls attention to interdisciplinary or multidisciplinary engagement among students. Such an arrangement could increase the number of students in STEM through a cohesive environment provided in K-12 schools and higher education institutions. One such model of a pedagogical approach in Texas is named T-STEM; it resulted in improved high school and college readiness of students on a large scale, enhanced the teaching capability of teachers, and recommended high-quality STEM education in an integrated form [1]. Another study was made on the adaptation of information and communication technology on the Middle East subcontinent in higher education institutes of Saudi Arabia. One thousand students observed the adoption of information and communication technology in a conservative environment. Interestingly, the results showed that female students had a better academic response to this adoption than their male counterparts [2]. Several factors affect the teaching skills development process regarding skills and tools related to pedagogy among K-12 teachers. Nadelson et al. studied such an attempt through short-term residential collaborative summer schools for the professional growth of teachers. The results showed gains in perceived efficacy and comfort, as well as in the knowledge relation of participants [3].

Figure 1 shows the last two decades' trends in article publications in related fields of STEM [4]. The graph shows the significant rise in approaches towards integration on subjects in STEM education and pedagogy. In pedagogy, several models have been formulated and discussed among education practitioners. Inquiry-based learning is one such approach, whose effectiveness is higher in science-based teaching and is recommended 
as a critical element in science pedagogy [5]. Inquiry-based learning is discussed in the article for further insight into the topic.
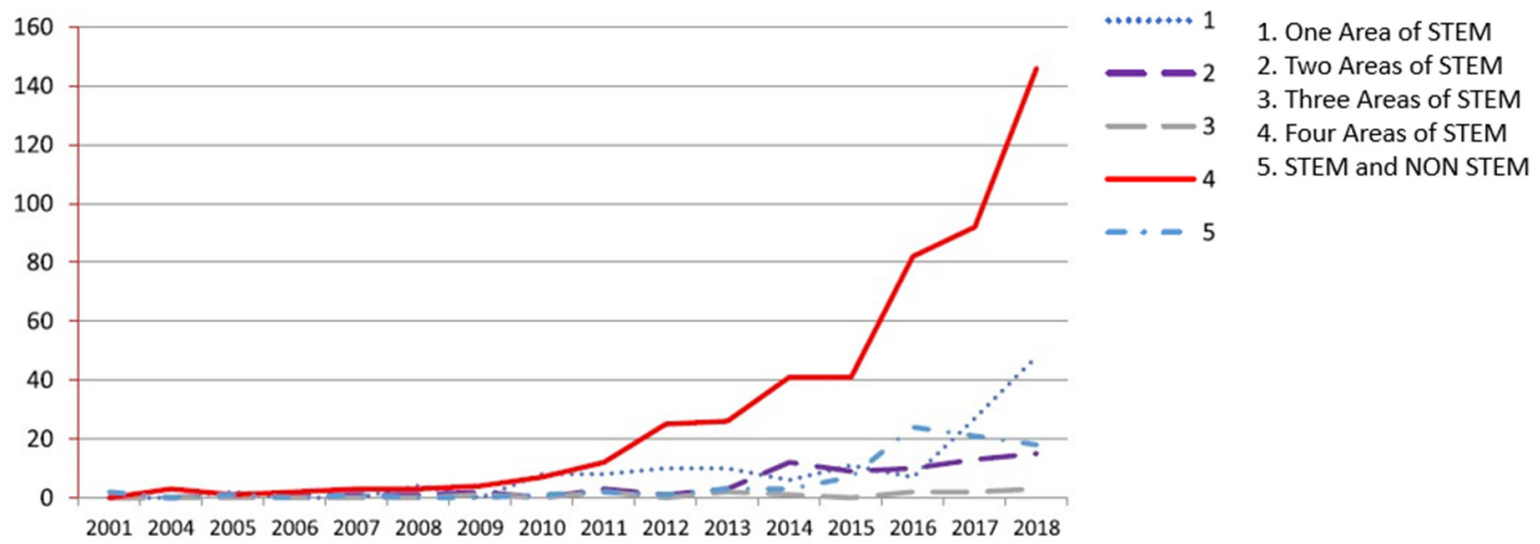

Figure 1. Trends in science, technology, engineering, and mathematics (STEM) publication based on content in STEM education [4].

This article focuses on the insights of various recent and novel pedagogical models in the background of STEM education. The research addresses the following questions:

- What role do novel models developed in pedagogical approaches play in STEM education?

- How has innovation in pedagogy evolved?

- Is inquiry-based learning a solution for the integration of STEM streams in pedagogy?

- How will pedagogy change after the pandemic?

\section{What Role Do Novel Models Developed in Pedagogical Approaches Play in STEM Education?}

The teaching staff of pre-service teachers can play a crucial role, as they have been found to be more open to technology integration [6]. The transformation in pedagogy is not only subject to intellectual progressiveness, but to societal progressiveness as well. Higher education institutions still face challenges in providing a robust framework for transformative pedagogy [7]. These renovations in pedagogy require specific novel models that work on integration in STEM. STEM educators should support a long-term progressive approach along with pedagogy tools with timely supervision in pedagogy. This could be a possible rightful direction in collaborative teaching education [8]. One such attempt was made in a joint study between Chinese and Russian universities by Liu et al., who conclude that "the introduction of the "interconnect" method, which implies a greater integration of subjects during the training, showed provably higher results than the "amalgam" method" [9].

Similarly, a 3D printing STE(A)M engineering design curriculum has been introduced into classes by high school educators. This approach helps students with hands-on experience in novel tools, makes educators workshop friendly, and enables both educators and students to develop friendly knowhow with peers [10]. Going paperless for a sustainable future was the impetus behind the creation of a platform for new teaching solutions via iPad usage in classrooms and laboratories. The University of New Haven designed a curriculum for honors students, including iPad and going paperless, that has had a positive effect on the millennial generation. They noted that educators on the platform should take the utmost care to clearly understand the concepts of the experiments available on the app [11]. In context to technical modeling solutions, a French university developed a course on "systems modeling" for engineering students by C. Stoica Maniu et al. in 2019. The study draws several conclusions, as follows: "From a scientific point of view, three main assets were realized. (i) This course offers the necessary framework allowing to choose the right model typology well-suited to the model objective (simulation, optimization, 
control, etc.): discrete/continuous state (or time), deterministic/stochastic, mechanistic (based on physical laws)/data-driven (based on measured data), frequency/time-based model. (ii) It provides analytic and numerical approaches to analyze the reliability of the developed models concerning uncertainty propagation, sensitivity analysis, selection of a model regarding certain specifications. (iii) Simulations and, more particularly, comparison with experimental data are developed." [12].

During the assessment, it was interesting to find out that classroom engagement is more frequent in the lower or middle level of the K-12 system. One possible reason for this could be that classroom engagement is more necessary in younger students. Kevin et al. tried three models named "Genie" and found that evidence-based e-learning for middle school students gave better results for classroom engagement [13]. Similarly, for high school students, Beumann et al. performed experiments based on the self-assessment of assignments [14]. In Ghana, a study suggests that a change in perception towards competency-based training can enhance quality education [15]. Multimodal quizzes in higher education also contribute more engagement, as engineering students were found to be able to avail formative assessment enhancing engagement [16].

Other possibilities of STEM integration have been discussed in some recent studies. Todd suggests that integrating STEM subjects in a proper form could be as complex as the global demand for new experts in STEM [17]. Integration at a higher level of education, such as engineering, still needs to be explored more [18]. STEM in a real sense needs a broader understanding and co-creation to attain the fundamental goals of STEM in K12 through integration [19]. Success in STEM integration cannot be achieved in a short time, as long as the expectations and outcomes for both learner and educator remain unaddressed [20]. Thus, significant focus is required in pedagogy to improve both classroom engagement and integration.

There is a very high dependence on online platforms in today's world, mainly from a K-12 perspective. The authors found that in order to understand the new modules, they should be analyzed in the context of their potential to integrate subjects and develop classroom engagement parallelly. In the last few years, many researchers have conducted experimental work by creating new modules, which directly or indirectly address these two aspects. We collected articles from all pedagogy ranges, like level of education, different countries, K 12, online education, etc. From our analysis, although they could be examined simultaneously, some showed better results in classroom engagement, while some had better integration capabilities, which is shown in Table 1.

\subsection{Formulation of a Novel Integrated STEM Tree}

In the perspective of K12 education, several models have been formulated by different researchers in pedagogy. A new question arises with the formulation of an integrated approach in pedagogy. We tried to analyze the perspective behind the integration of various streams of STEM. STEM education can be a bridge between the knowledge gaps investigated by various researchers around the world. Recently, many models have been developed by educators, some of which support integration and others that do not. The new novel STEM tree, shown in Figure 2, was formulated based on the model understanding. Our analysis also suggests that online education must be complemented with online assessment. This is not only important in the K12 perspective, but also in higher institutions of engineering and sciences. Educators must also upgrade themselves by making good use of the online teaching tools that are currently available. The increase of female participation in many studies revealed better outcomes in higher education when the model had an integrated approach. Educators not only need to change their subject-based mindset, but also need to upgrade themselves with modern and intelligent tutoring. The idea behind the STEM tree formulation is to provide a model solution for the integration of various subjects. 
Table 1. Models in pedagogical approaches for STEM education.

\begin{tabular}{|c|c|c|c|c|c|}
\hline No. & $\begin{array}{l}\text { Models Developed in } \\
\text { Pedagogy }\end{array}$ & Field & Objectives & Year & Ref. \\
\hline 1. & Genie model & $\begin{array}{l}\text { Classroom } \\
\text { engagement }\end{array}$ & Incorporating effective E-learning in middle schools & 2015 & [13] \\
\hline 2. & Conceptual framework & STEM integration & $\begin{array}{l}\text { Introducing a conceptual framework for } \\
\text { integrated STEM }\end{array}$ & 2016 & [17] \\
\hline 3. & K-12 model & STEM integration & STEM integration with equitable focus on all streams & 2016 & [18] \\
\hline 4. & Self-assessment model & $\begin{array}{c}\text { Classroom } \\
\text { engagement }\end{array}$ & $\begin{array}{c}\text { Promoting self-assessment assignments in } \\
\text { higher education }\end{array}$ & 2018 & [14] \\
\hline 5. & $\begin{array}{l}\text { Competency-based } \\
\text { training }(\mathrm{CBT})\end{array}$ & $\begin{array}{c}\text { Classroom } \\
\text { engagement }\end{array}$ & $\begin{array}{l}\text { Promoting CBT in universities of Ghana for } \\
\text { employable student skills }\end{array}$ & 2018 & [15] \\
\hline 6. & $\begin{array}{l}\text { Design-based } \\
\text { learning-Makerspace }\end{array}$ & STEM integration & $\begin{array}{l}\text { Study based on motivational factors affecting } \\
\text { elementary students }\end{array}$ & 2018 & [21] \\
\hline 7. & $\begin{array}{l}\text { Play-based } \\
\text { learning model }\end{array}$ & $\begin{array}{c}\text { Classroom } \\
\text { engagement }\end{array}$ & $\begin{array}{l}\text { Use of apps to understand the impact of } \\
\text { interactive technology }\end{array}$ & 2018 & [22] \\
\hline 8. & $\begin{array}{l}\text { Sense Making model } \\
\text { (SMM) }\end{array}$ & STEM integration & To investigate educators conceptualization of STEM & 2018 & [19] \\
\hline 9. & $\begin{array}{l}\text { Intelligent tutoring } \\
\text { systems (ITS) }\end{array}$ & STEM integration & To understand effectiveness of ITS in STEM & 2018 & [23] \\
\hline 10. & SKOPE IT & STEM integration & To investigate the efficiency of portable ITS in STEM & 2018 & [24] \\
\hline 11. & $\begin{array}{l}\text { Learning assistant } \\
\text { program }\end{array}$ & STEM integration & $\begin{array}{c}\text { Development of pedagogical knowledge in } \\
\text { learning assistants }\end{array}$ & 2018 & [20] \\
\hline 12. & $\begin{array}{l}\text { Integrated STEM black } \\
\text { box }\end{array}$ & STEM integration & To address ill-defined gaps of integrated STEM & 2018 & [25] \\
\hline 13. & $\begin{array}{l}\text { Growing tall poppies } \\
\text { program }(\mathrm{GTP})\end{array}$ & $\begin{array}{c}\text { Classroom } \\
\text { engagement }\end{array}$ & $\begin{array}{l}\text { To promote students to take STEM subjects in } \\
\text { higher studies }\end{array}$ & 2019 & [26] \\
\hline 14. & $\begin{array}{l}\text { Learning management } \\
\text { system (LMS) }\end{array}$ & $\begin{array}{c}\text { Classroom } \\
\text { engagement }\end{array}$ & $\begin{array}{l}\text { To investigate the use of multimodal quizzes in } \\
\text { replacing conventional assessments }\end{array}$ & 2019 & [16] \\
\hline 15. & $\begin{array}{l}\text { Peer supplemental } \\
\text { model }\end{array}$ & STEM integration & $\begin{array}{l}\text { To understand innovation in } \\
\text { supplemental instructions }\end{array}$ & 2020 & [27] \\
\hline
\end{tabular}

\subsection{Integration of Streams in Pedagogy}

The integration of various streams like mathematics, science, and technology is an inevitable development for both students and educators in the 21st century. This approach requires adequate knowledge of the field in order to formulate the integration of various streams of study [28]. The integration of pedagogy is presented in a pictorial representation in Figure 3, which frames the flow of the proposed idea to termination, keeping in view the four pillars of STEM, i.e., science, technology, engineering, and mathematics. The integration of various subjects in STEM education requires a proper framework for induction in educational institutes. An adequate flow model for its implementation can achieve this.

Figure 3 provides a brief idea of the flow structure. Integration can only be achieved if an appropriate framework is provided in the teaching institution's curriculum. The integration of streams is not an easy task for an educator. The content of various subjects can be combined in the form of a project, which can make the job easier for the teacher. Project-based learning creates an out-of-the-box thinking approach in the student. Any form of integration in today's situation is incomplete without the digitalization of classrooms. Any modification in the context of education is preliminary without proper incorporation in the curriculum. Once modification is incorporated into the school's curriculum, it provides cohesiveness between the students and educators. Thus, the integration flow model provides a pathway to channel STEM content properly for improved pedagogy. 


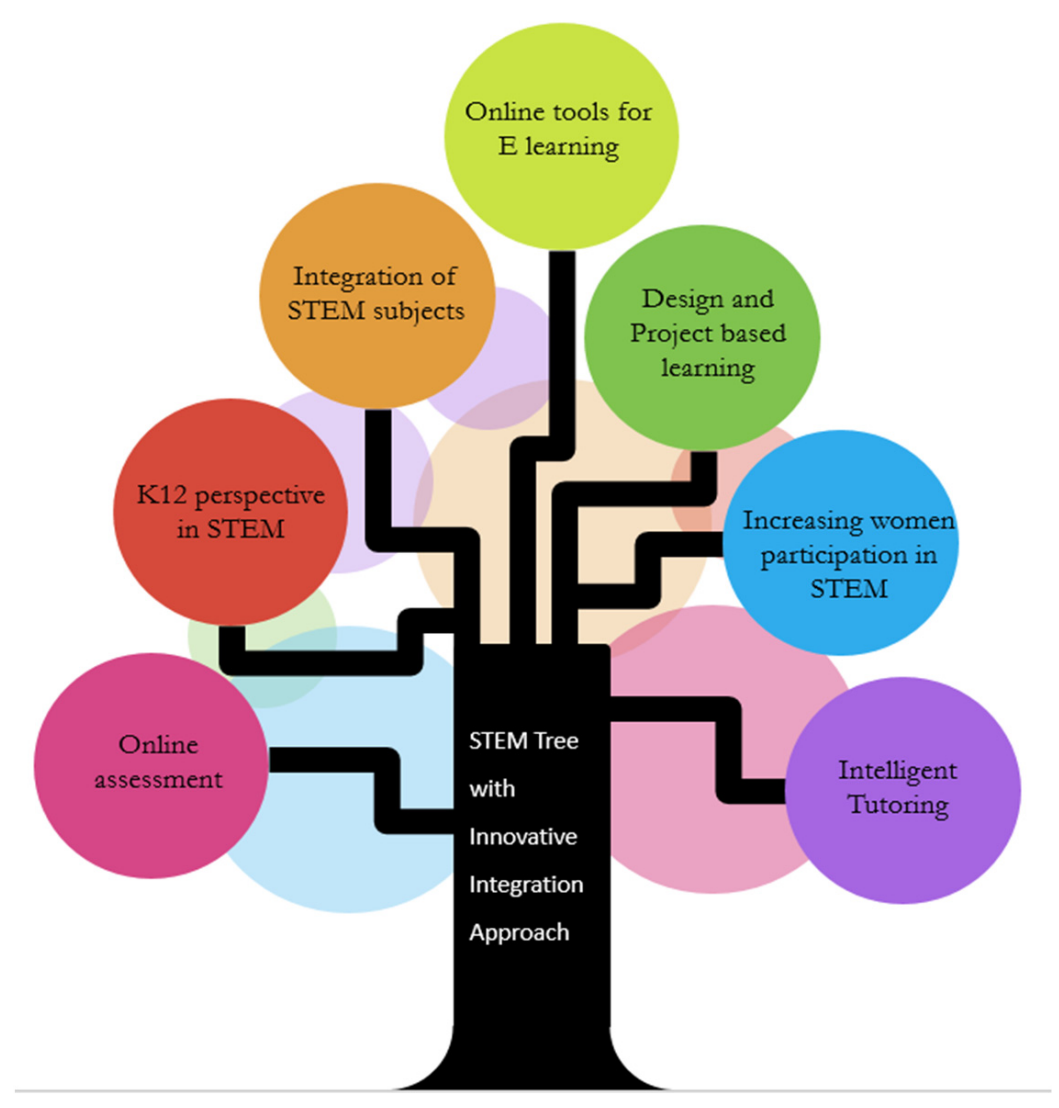

Figure 2. STEM tree with an innovative integration approach.

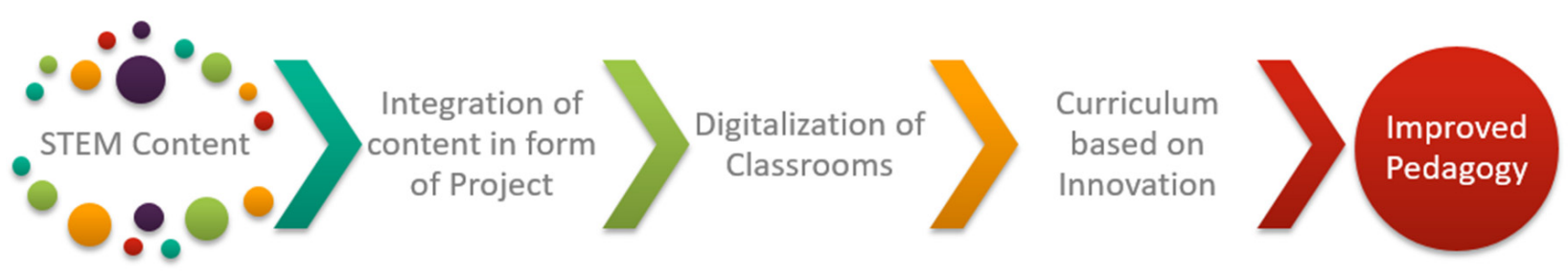

Figure 3. Integration flow in pedagogy.

\section{How Has Innovation in Pedagogy Evolved?}

Innovation in STEM integration is a mechanical gear-like system in which one part is interdependent to run the cycle smoothly. Knowledge of pedagogy and technical content, when combined with digitalization, creates a platform or space for innovation.

From the analysis and observations compiled in Table 1, it is evident that the pedagogy depicted in Figure 4. is evolving very quickly. Here, we tried to represent a novel model for the integration of subjects in STEM. It is recommended to combine the traditional content knowledge and pedagogical knowledge with upgraded e-learning knowledge. The technical content knowledge, for example, in engineering streams, must be enhanced with digital teaching platforms. The future study perspectives for the K12 pedagogy demand the incorporation of online and e-learning platforms in the curriculum. These changes could bring about fruitful results for STEM students at higher levels of education. In addition, online applications and platforms of learning make K12 students better prepared to grasp the technical parts of courses faster. 


\subsection{Suggested New Skill Set Requirements}

Over time, it has been observed that pedagogy and skill development among educators are crucial factors influencing various facets of STEM learning. Different parts of the world have unique problems and approaches; therefore, the modality of skills requirement is multidimensional, and requires a comprehensive outlook. The incorporation of information and communication technology in STEM and pedagogy are ever-changing. After every decade, the models of online platforms change. Theoretical competence among educators can be observed in various studies, but practical knowhow is the key. These new models and approaches will foster educators' skill sets and encourage students to engage with STEM and its integration into coursework.

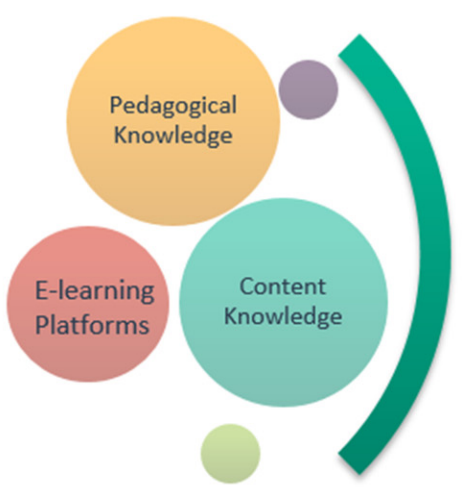

Pedagogical Content Knowledge

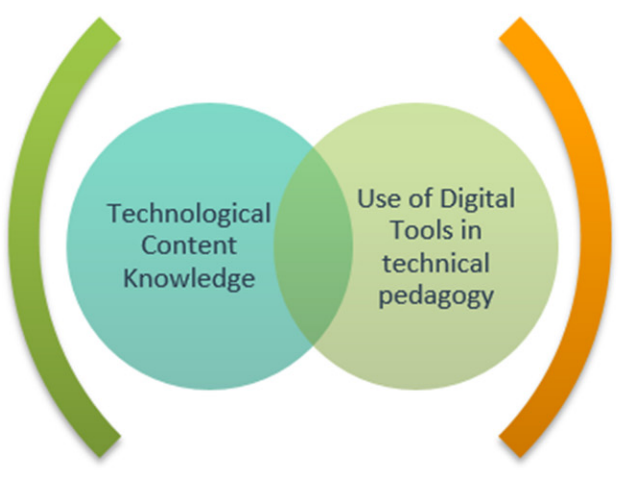

Technical Content Knowledge

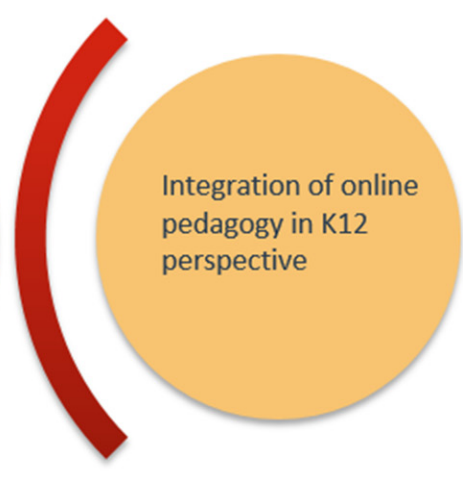

Technical pedagogical knowledge

\section{INNOVATION IN STEM INTEGRATION}

Figure 4. Representation of innovation in STEM integration.

In STEM, many innovative tools are catching up, such as innovative transparent boards for lecturers in classrooms, whose use has resulted in better post-tests results among students [29]. Apart from creative skills, spatial skills also have a significant impact on the improvement of STEM pedagogy [30]. Kirsch et al. investigated an exciting approach to translanguaging and supported multilingual pedagogy's implications for young children [31]. Another bilingual case study on classroom reading sessions suggests special attention for students with more than one language background [32]. One survey from England revealed that the traditional skill-sets in pedagogy are not enough, and that timely intervention for skill improvement is essential [33]. Specific scientific tools, such as computer-aided design tools (CAD), are essential in educator's skill up-gradation [34].

To strengthen the approach for inquiry-based learning, it is vital to understand the shortcomings in the current methods. In Table 2. we tried to investigate the gaps and the skills required to upgrade pedagogy. It was observed from studies that the improvement required has a broad spectrum. The pedagogy models have to be collaborative. The traditional pedagogy models need more flexibility. The courses need to be adaptable, as the situation of classrooms is not equal in all places. Sometimes, educators need to focus on other aspects such as language or gender equality. The experimental setups are also changing drastically. Virtual laboratories and experiments could evolve in the coming years. Various tools such as ChemSketch, cloud modeling, or Golabs can help in equipping educators in pedagogy. Along with tools, the development of skill sets is vital. 
Table 2. Recently developed skills-based pedagogy approaches.

\begin{tabular}{|c|c|c|c|c|}
\hline Number & Study Approach & Current Shortcomings Observed & Skills Suggested under the Pedagogy & Ref. \\
\hline 1. & $\begin{array}{l}\text { Improvement in STEM at } \\
\text { liberal arts college }\end{array}$ & $\begin{array}{l}\text { Low retention in STEM for a lower } \\
\text { financial class of students }\end{array}$ & $\begin{array}{l}\text { Research temperament development } \\
\text { among teachers with field experience } \\
\text { of laboratories }\end{array}$ & [35] \\
\hline 2. & $\begin{array}{l}\text { Introduction of Supplemental } \\
\text { model for better STEM and } \\
\text { skill transferability }\end{array}$ & $\begin{array}{l}\text { Gaps in STEM diversification at high } \\
\text { school level and at undergraduate level } \\
\text { teaching, e.g., college course work and } \\
\text { independent study }\end{array}$ & $\begin{array}{l}\text { A modified peer supplemental model } \\
\text { comprehensive of metacognitive skills, } \\
\text { collaborative learning, and active learning }\end{array}$ & [27] \\
\hline 3. & $\begin{array}{l}\text { Focus on female high school } \\
\text { students as an untapped } \\
\text { STEM resource }\end{array}$ & $\begin{array}{c}\text { STEM education programs around the } \\
\text { world increase, but with a considerably } \\
\text { lower number of female students } \\
\text { and teachers }\end{array}$ & $\begin{array}{l}\text { Broadening STEM areas in social } \\
\text { psychological skills to build girls' } \\
\text { confidence in STEM and uncapping their } \\
\text { potential as resources }\end{array}$ & [26] \\
\hline 4. & $\begin{array}{l}\text { Improvement in the learning } \\
\text { experience through } \\
\text { innovative lectures }\end{array}$ & $\begin{array}{l}\text { Experimental comparison of online } \\
\text { learning experience in lectures through } \\
\text { regular whiteboards and } \\
\text { transparent boards }\end{array}$ & $\begin{array}{l}\text { Focus on multimedia learning, social } \\
\text { agency, and designing study material for } \\
\text { online STEM students }\end{array}$ & [29] \\
\hline 5. & $\begin{array}{l}\text { Information and } \\
\text { communication training in the } \\
\text { initial training of teachers } \\
\text { in pedagogy }\end{array}$ & $\begin{array}{l}\text { The deficit in the knowhow of digital } \\
\text { tools complements digital awareness } \\
\text { among teachers and students }\end{array}$ & $\begin{array}{l}\text { The requirement of good and enhanced } \\
\text { digital competency of teachers in online } \\
\text { availability of tools to be incorporated in } \\
\text { online pedagogy }\end{array}$ & [36] \\
\hline 6. & $\begin{array}{l}\text { Importance of spatial cognitive } \\
\text { skills in STEM education }\end{array}$ & $\begin{array}{l}\text { Retention of women in engineering } \\
\text { studies and its positive effects were } \\
\text { analyzed through regressive analysis }\end{array}$ & $\begin{array}{l}\text { Spatial skills intervention in coursework } \\
\text { demonstrates better retention proportion } \\
\text { for women in engineering }\end{array}$ & [30] \\
\hline 7. & $\begin{array}{l}\text { Importance of translanguaging } \\
\text { and its challenges in pedagogy }\end{array}$ & $\begin{array}{c}\text { Issue of social inequalities among STEM } \\
\text { students persist because of } \\
\text { linguistic barriers }\end{array}$ & $\begin{array}{l}\text { Development of translanguaging skills } \\
\text { among teachers and students through } \\
\text { professional development courses }\end{array}$ & [31] \\
\hline 8. & $\begin{array}{l}\text { Reading comprehension } \\
\text { approach in pedagogies in } \\
\text { multimodal ways }\end{array}$ & $\begin{array}{l}\text { The deficit in multimodality of younger } \\
\text { bilinguals in reading comprehension }\end{array}$ & $\begin{array}{l}\text { Improvement in multimodality facets of } \\
\text { textual reading in classrooms rather than } \\
\text { conventional comprehensive reading }\end{array}$ & [32] \\
\hline 9. & $\begin{array}{l}\text { Importance of subject } \\
\text { specialist approach } \\
\text { in pedagogy }\end{array}$ & $\begin{array}{l}\text { The less observed focus of } \\
\text { subject-specific expertise } \\
\text { among educators }\end{array}$ & $\begin{array}{l}\text { Positive impacts of subject-specific skills } \\
\text { focus in pedagogy; results show } \\
\text { positive impacts }\end{array}$ & [33] \\
\hline 10. & $\begin{array}{l}\text { Flipped classroom strategies in } \\
\text { pedagogy for } \\
\text { secondary students }\end{array}$ & $\begin{array}{l}\text { To enhance the digital classroom learning } \\
\text { among school students with online social } \\
\text { learning platforms }\end{array}$ & $\begin{array}{c}\text { Critical thinking skills development } \\
\text { demonstrated a better capability among } \\
\text { students in hypothesis identifications } \\
\text { and induction }\end{array}$ & [37] \\
\hline 11. & $\begin{array}{l}\text { Impact of early-stage exposure } \\
\text { to STEM streams on } \\
\text { academic achievements }\end{array}$ & $\begin{array}{l}\text { The shortfall in American students' } \\
\text { academic achievement compared with } \\
\text { peer country students }\end{array}$ & $\begin{array}{l}\text { Informal learning, increase in the } \\
\text { interactivity of teachers and students, and } \\
\text { touchscreen devices' adaptability in } \\
\text { STEM courses }\end{array}$ & [38] \\
\hline 12. & $\begin{array}{l}\text { Influence of Computer-aided } \\
\text { design coursework in } \\
\text { STEM pedagogy }\end{array}$ & $\begin{array}{l}\text { The decline in student interest in science } \\
\text { and math in STEM courses }\end{array}$ & $\begin{array}{l}\text { Implementation of computer-aided design } \\
\text { tools in pedagogy such as 3D in the early } \\
\text { stages of STEM integration }\end{array}$ & [34] \\
\hline 13. & $\begin{array}{l}\text { Use of visualization tools in } \\
\text { STEM education }\end{array}$ & $\begin{array}{l}\text { Low confidence in students who are less } \\
\text { college-ready than peers to adopt } \\
\text { STEM courses }\end{array}$ & $\begin{array}{l}\text { Skills-based on visualization tools such as } \\
\text { ChemSketch, ParaView, and } \\
\text { computational visualization }\end{array}$ & [39] \\
\hline 14. & $\begin{array}{l}\text { Cloud-based simulation } \\
\text { service for high school } \\
\text { STEM education }\end{array}$ & $\begin{array}{l}\text { Considerable lack in teaching modalities } \\
\text { to overcome real-world project problems }\end{array}$ & $\begin{array}{l}\text { Incorporation of cloud modeling and } \\
\text { simulation skills for project learning } \\
\text { pedagogy activities }\end{array}$ & [40] \\
\hline 15. & $\begin{array}{l}\text { Virtual laboratories } \\
\text { and teaching } \\
\text { methods development }\end{array}$ & $\begin{array}{l}\text { Challenges faced by STEM educators in } \\
\text { upscaling lab activities and experiments } \\
\text { through online portals }\end{array}$ & $\begin{array}{l}\text { Promotion of young mindful pedagogy } \\
\text { educators with online lab skills } \\
\text { development through platforms such as } \\
\text { GoLabs to enhance inquiry learning }\end{array}$ & [41] \\
\hline
\end{tabular}

\subsection{Skill-Set Balancing-A Solution for Skill Matrix Analysis}

Various authors have provided outlook requirements of educators in pedagogy. The research gaps observed by them are compiled in Table 3, along with their recommended skill-set suggestions. Knowledge gaps in the study and required skills, therefore, require balance in the formulation. In addition, various factors influence the identification of the 
required skill sets. Figure 5 is a representation of the balancing parameters to be considered in STEM pedagogy.

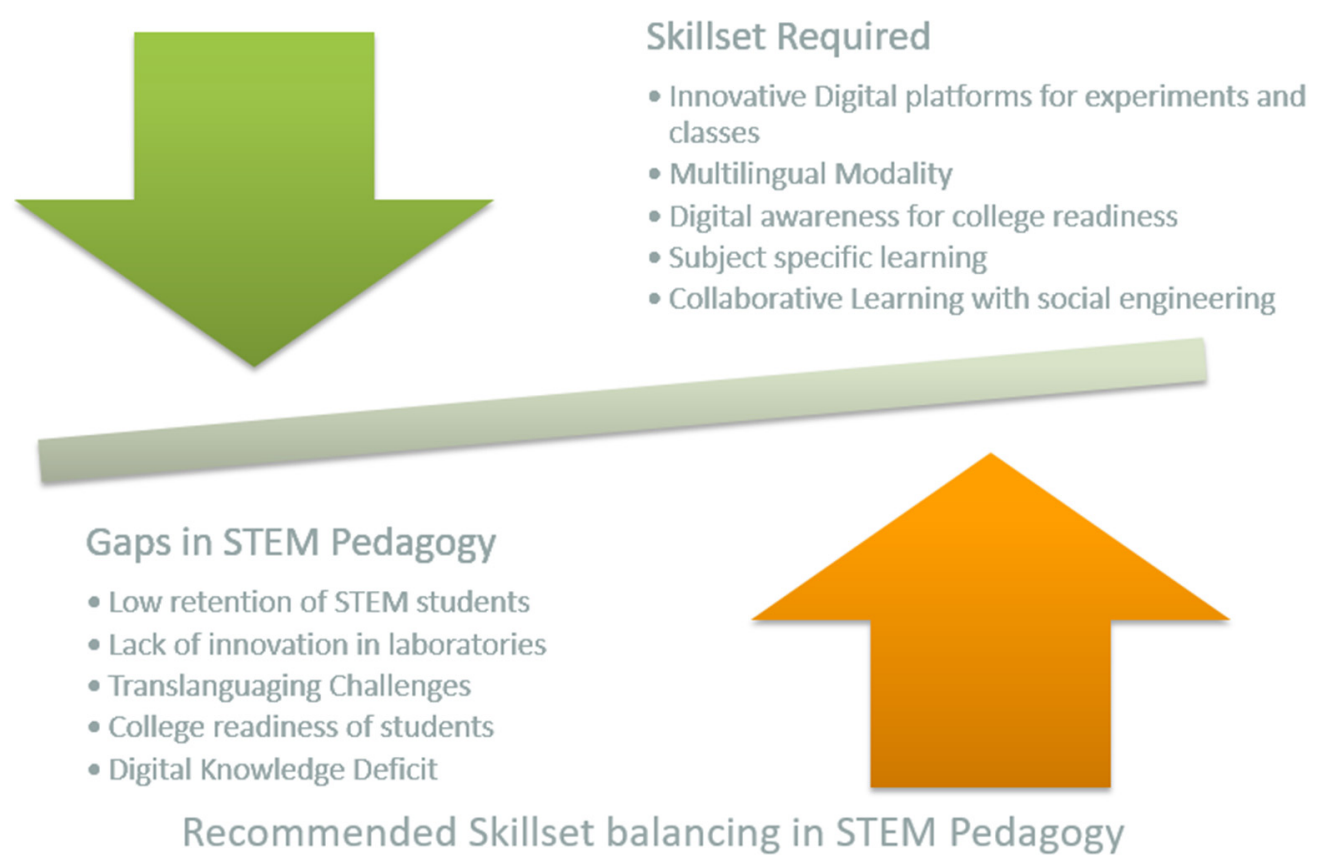

Figure 5. Skill-set balancing in STEM pedagogy.

Student retention is a big problem at the higher education institutional level because of lower college readiness among students. Many students suffer from language barrier issues, and as a result a significant portion of students choose not to go to college. Digital content deficit among teachers and low adaptability between students degrade the learning enthusiasm in classrooms. Therefore, the recommended skill set should be based on the gaps. Henceforth, balancing is required between the two. Skill-set balancing is an attempt to frame a cohesive environment inside the classroom. The teacher needs to understand the student's native language with a multilingual modality so that the students want to learn more and feel comfortable. This approach will enhance the social engineering of the classroom, and it will make the study joyful. The class's digitalization will also increase student retention ratios and prepare them for college early in the K12 study module. Thus, various educators can adopt skill-set balancing to analyze the gap and act accordingly for improved pedagogical results. This balancing could also be a potential analysis tool for policymakers at institutional levels.

\section{Is Inquiry-Based Learning a Solution for the Integration of STEM Streams in Pedagogy?}

The big gap between knowing and doing is well described by Gowin's modified Vee diagram in Figure 6. Here, we assessed the recent inquiry-based learning (IBL) methodology adopted by some researchers, as well as their outcomes. The cycle of converting initial ideas to final claims has to go through the process described in Table 3. The studies hypothesis and their supporting evidence give a broad idea of the studies based on IBL. 
Table 3. Compilation of recent studies on inquiry-based learning in STEM pedagogy.

\begin{tabular}{|c|c|c|c|}
\hline Number & The Hypothesis of the Study in IBL Approach & Supporting Evidence for IBL in Pedagogy & Ref. \\
\hline 1. & $\begin{array}{l}\text { Testimony of inquiry approach in texts and } \\
\text { experiments through virtual labs }\end{array}$ & $\begin{array}{l}\text { Integration fosters inquiry and scientific temperament } \\
\text { among students through virtual labs }\end{array}$ & [43] \\
\hline 2. & Use of IBL apps for science education & $\begin{array}{l}\text { Functional features of learning apps help in science } \\
\text { exploration and conceptualizations }\end{array}$ & [44] \\
\hline 3. & $\begin{array}{l}\text { Enhancement in STEM majors for IBL approach } \\
\text { in undergraduate math and science lessons }\end{array}$ & $\begin{array}{l}\text { Explicit teaching models in the pedagogy of educators } \\
\text { are found fruitful for IBL and STEM majors integration }\end{array}$ & [45] \\
\hline 4. & $\begin{array}{l}\text { Predict, observe, explain, and evaluate (POEE) } \\
\text { scaffolding approach was implemented in two } \\
\text { IBL modules }\end{array}$ & $\begin{array}{l}\text { Results support the design shift paradigm change in } \\
\text { independent learning and also promote adaptability } \\
\text { in self-directed learning }\end{array}$ & [46] \\
\hline 5. & $\begin{array}{l}\text { Computer-supported collaborative IBL with } \\
\text { critical thinking development }\end{array}$ & $\begin{array}{c}\text { Tasks performed on joint simulation study in IBL gave } \\
\text { better support among students for } \\
\text { experimental studies }\end{array}$ & [47] \\
\hline 6. & $\begin{array}{c}\text { Introduction of mobile-IBL in English education } \\
\text { as a foreign language with the effectiveness of } \\
\text { the motivational design }\end{array}$ & $\begin{array}{l}\text { Results show higher motivation levels in added } \\
\text { elements module with attention, relevance, confidence, } \\
\text { and satisfaction (ARCS) }\end{array}$ & [48] \\
\hline 7. & $\begin{array}{l}\text { Co-relation of pedagogical content knowledge } \\
\text { and ideological clarity and its impact }\end{array}$ & $\begin{array}{l}\text { Critical historical IBL, when coupled with clarity on } \\
\text { content knowledge and ideology, presents better } \\
\text { outcome in pedagogical outputs }\end{array}$ & [49] \\
\hline 8. & $\begin{array}{l}\text { Cognitive learning in STEAM IBL of } \\
\text { math modules }\end{array}$ & $\begin{array}{l}\text { The fusion of informal math modules in the STEAM } \\
\text { (STEM + arts) framework leads to better mental } \\
\text { knowledge and visual reasoning }\end{array}$ & [50] \\
\hline
\end{tabular}

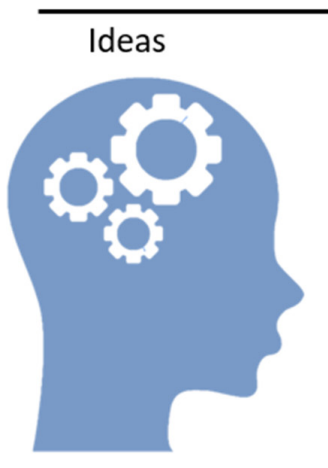

Conceptualization

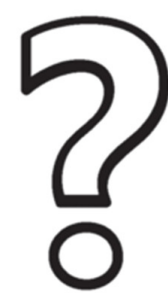

Knowledge Gap

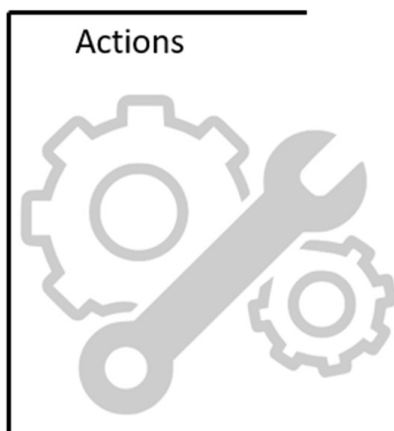

Analysis with Expert Opinions

Figure 6. Gowin's modified Vee Diagram [42].

A recent online IBL study revealed that integrating informal texts and virtual laboratories can enhance learning, but further validation is required in the integration aspects [43]. Learning modules with IBL are now also available on smartphones via apps. However, these apps also need to incorporate pedagogical viewpoints [44]. Surveys have observed that enhancing STEM majors' learning capacity in undergraduate studies could produce better results $[45,46]$. Hence, undergraduate studies could focus on IBL majors in the curriculum. In addition, collaborative IBL is recommended for in-group studies through messages as sharing knowledge [47]. These are some innovative methods found in IBL explorations. Similarly, motivational strategies could also be incorporated in mobile IBL through learning motivations and accomplishments [48]. Educators are highly motivated to carry out these efforts when they are coupled with ideological clarity and pedagogical content knowledge [49]. On the other hand, autonomy and visual reasoning are some other tools that significantly help enhance IBL [50]. 
Hypothesis and the choice of methodologies followed are critical aspects of research output. It has been found that in today's world of online education, virtual labs and mobile apps could jointly enhance an IBL approach among students. Computer-based learning models are not only innovative, but also foster easy accessibility to learning updated integrated technologies. The fusion of STEM with arts to create STE(A)M is yet another way to create reasoning and cognitive skills among students. Our analysis also leads us to recommend having expert clarity on subjects before forming any model approach. The improved IBL models can only be successful if they are backed with proper content knowledge.

\section{Matrix Analysis of IBL in STEM}

Future technologies are primarily dependent on academic studies in the classrooms of mid-level and higher-level educational institutes. Efficacy in learning science and technology largely depends on the art of questioning in science and mathematics. The inquiry-based learning approach provides a feel of involvement among students and gives them an idea of classroom learning achievement. The more that students feel inclined towards questioning what they learn, the more joyful learning becomes to them.

The matrix analysis attempts to understand the gaps between the future trainers and the innovations required in IBL. The matrix is flexible and could be applied to any level of hierarchical studies in pedagogy, as shown in Figure 7. Educators need to identify gaps and create their metrics depending on the situation and requirements. From the starting position of the analysis, namely the gaps identified, the creators can reach future readiness by identifying possible drawbacks.

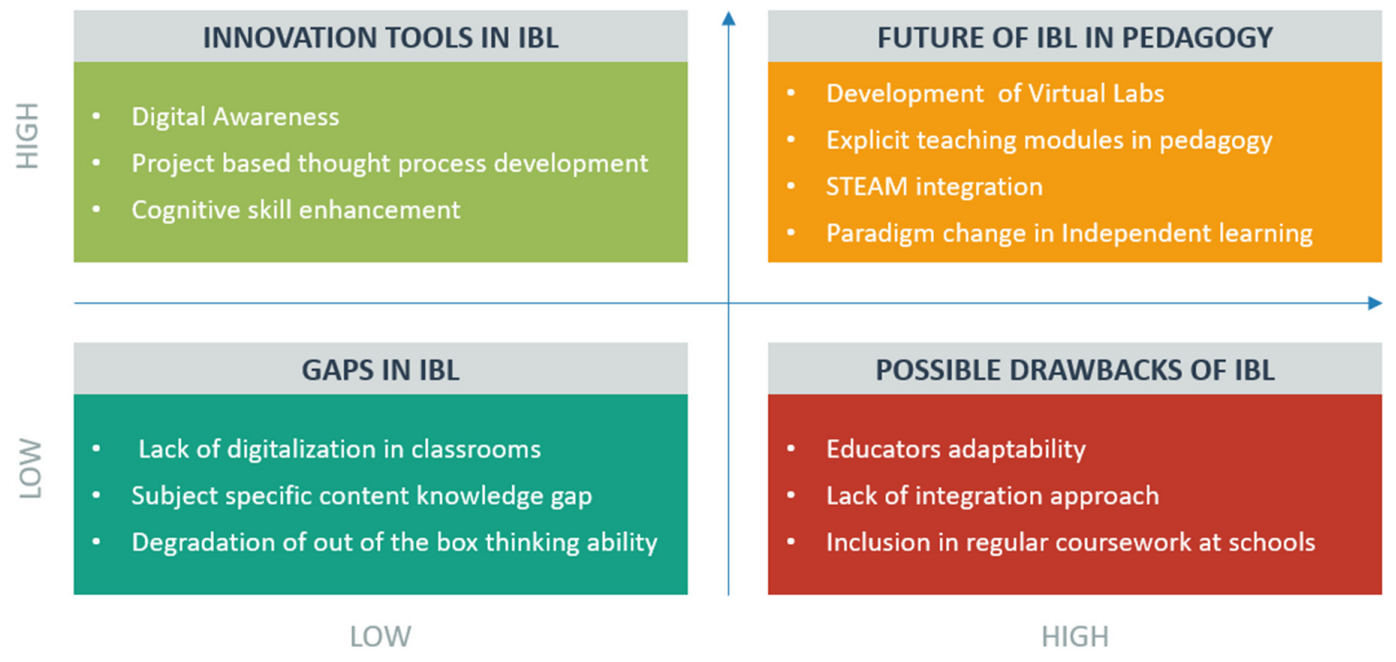

Figure 7. High and low matrix for inquiry-based learning (IBL)in pedagogy.

The future is changing very quickly with technologies and platforms such as artificial intelligence and cloud data computing. STEM educators are committed to cope up with the new models. The future of pedagogy will be governed by how efficiently educators can present their content knowledge in collaboration with e-learning tools and develop inquiry-based learning in classrooms, especially in STEM classrooms.

\section{How Will Pedagogy Change Post-Pandemic?}

The sudden shock of the pandemic of 2020 severely affected economies, health, and industrial sectors, as well as education systems, and their policies. Education systems, schools, and educators have had to adapt as best they can. Developing and developed nations have all suffered the pandemic and its aftereffects. This situation raises the question of the post-pandemic nature of pedagogies and tools in STEM education. 
The primary concern in schools, colleges, and research institutes emerged with government authorities' lockdown situations. Classes suddenly had to make a transition to online instruction. The readiness of pedagogy educators and management is still an issue. Such a situation has not been observed on such a massive global scale in recent times. The educators trained for face-to-face pedagogy were forced to look for online solutions in pedagogy.

Some notable recommendations in dealing with pedagogy framework in the context of developing countries as per study are below: [51]

- Recognition of disparities;

- Technical assistance in pedagogy;

- Transitions in a proper timeframe;

- Proper training sessions for educators;

- Online tools modality assessment;

- Streamlining the teaching schedules;

- Alternative assessment framework in schools.

The pandemic has had repercussions not only on the educators, but on students as well. Students and educators around the world have suffered depression, anxiety, and mood swings. For instance, a study in Brazil on pharmaceutical sector students revealed a higher level of anxiety, anger, and mood swings during the pandemic period [52]. The relevance of mental health is important in pedagogy because these symptoms have also been observed among educators and management staff. Such an analysis highlights the importance of the narrative about health concerns in the pedagogy and education sector. For example, one study carried out a strength, weakness, opportunity, and threat (SWOT) analysis in the context of the health and educational sector [53].

\subsection{The PESTLE Approach in Post-Pandemic Pedagogy}

Political, economic, social, technological, legal, and environmental (PESTLE) analysis is a tool that supports business companies for the marketing and identification of product readiness on the various mentioned parameters, as shown in Figure 8. It fits in pedagogy because these parameters were relevant to administrators and educators during the postpandemic scenario of 2020. The outlook towards the education system has changed in the eyes of parents, students, and lawmakers as a result of the pandemic. Thus, it becomes inevitable to disrupt the less cognitive old system and bring in a new one that addresses the issue in a broader context. A descriptive layout has been provided in Figure 8 in the context of pedagogy in STEM.

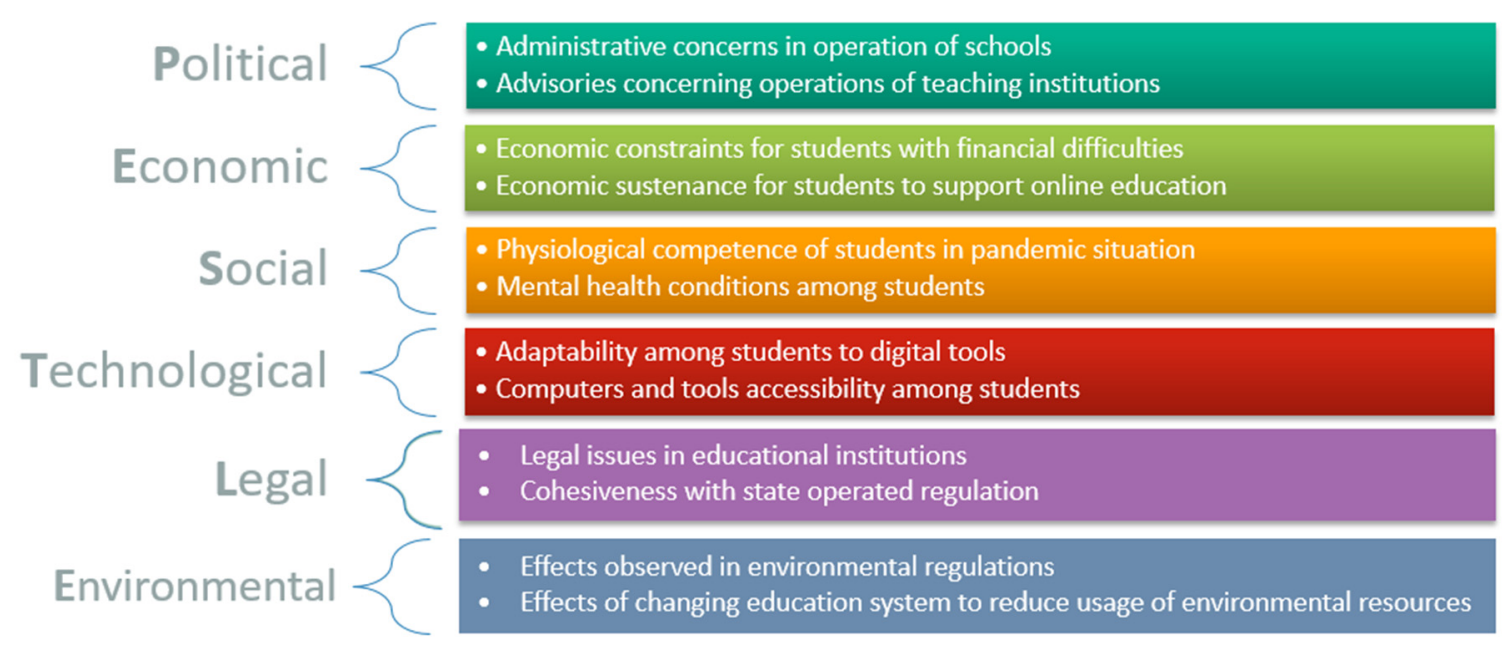

Figure 8. Political, economic, social, technological, legal, and environmental (PESTLE) analysis of STEM pedagogy in post-pandemic conditions. 
The PESTLE analysis could be an effective tool in managing such emergencies and logically understanding the situation to take the necessary steps. This approach covers understanding from the educator's point of view and the students as well. It also has a place for the political and legal entities involved in the decision-making process, making it administration friendly.

\subsection{Conditional Matrix}

A conditional matrix is a tool that provides a cognitive analysis of the most favorable actions in emergencies. It can work as an extension to the PESTLE analysis. After proper identification of the parameters of concern in PESTLE, the matrix helps to make quick decisions for running STEM education. Pedagogy will suffer less if all concerns are adequately addressed in the matrix. It gives educators a broad sense of understanding to shift the classrooms from physical presence to online platforms quickly, as shown in Figure 9 .
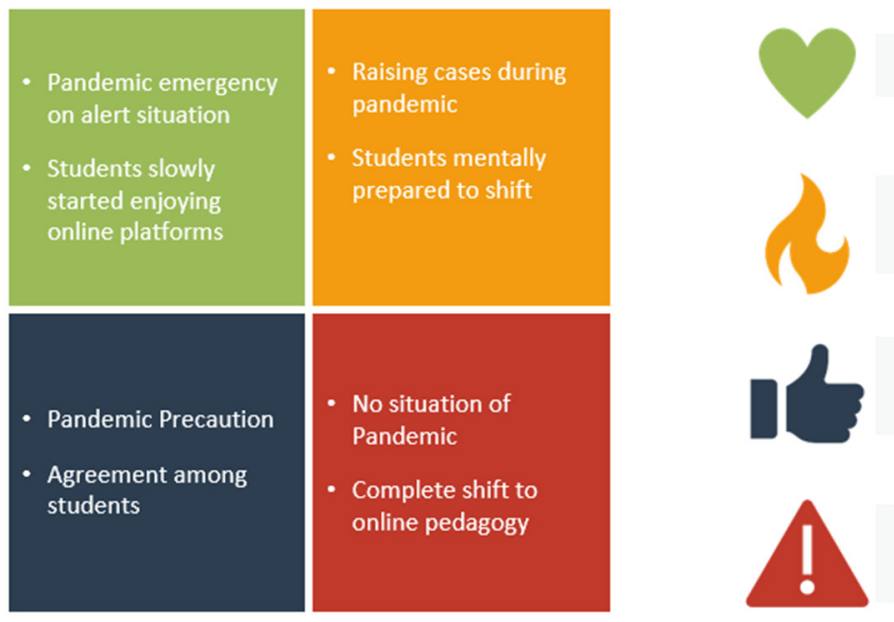

Favorable conditions for online pedagogy.

Less likely condition to shift to online platforms

Minimum conditions satisfied to shift to online education

Not recommended to shift completely to online education system

Figure 9. Conditional matrix for post-pandemic pedagogy in STEM.

The proper implementation of the conditional matrix and PESTLE analysis can play a crucial role in educational institutes' decision-making process for continuing education in emergencies.

\section{Discussion}

In this article, we attempt to identify the gaps or challenges faced by STEM educators in pedagogy. Various models have been developed recently that deal with developing different novel models for pedagogy, and this review focuses mainly on publications from the last five years, and these models are new and user-friendly. Several models of pedagogical content knowledge have also been discussed in terms of innovation in combining the benchmark idea of technological pedagogical content knowledge [54]. The novel models are a way forward for educators in the critical pedagogy approach.

Analysis of the socioemotional content in pedagogy can lead to better outcomes if educators also use emotional quotient (EQ) in STEM pedagogy [55]. Inquiry-based learning could be the torchbearer approach to teaching higher education STEM-based research in science and technology if educators are familiar with the methods. This module is a boon to research academicians when the educators are adequately motivated. Scaffolder Vee diagrams provide deep insight into STEM pedagogy by providing a step-by-step module on analytical thinking development both to educators and students [42].

The models discussed in this article cannot be fruitful unless the different STEM streams are joined together in an innovative platform. The STEM tree can flourish better with a nexus of amalgamated knowledge fields under one roof housing knowledge. 
This result shows that pedagogy needs a holistic approach from researchers-as well as educators-for providing better solutions for evolved future learning among students. This aim could be achieved by thorough knowledge of the actual ground situation and creating a framework parallel to the basic requirements. Digitalization and modern online tools can provide a framework, but not completely replace the existing physical education system. However, online tools can serve as a lubricant in pedagogy's proper and smooth functioning in STEM.

\section{Conclusions}

The modernization of stem education cannot be differentiated using a black or white perspective. STEM consists of various shades of grey. Optimization of skill-sets and related tools can only serve as a solution when merged with innovation. There cannot be any single concrete solution to STEM pedagogy modification, as the world is ever-changing, and so are teaching methodologies. The answer to all these queries of modernization lies in finding suitable parameters that affect the pedagogy. When combined with the best fitting model rightly placed with a current situation, the proper parameters can bear fruitful results.

Any comprehensive study on the various facets of pedagogy brings multiple aspects to its futuristic approach. Our research brings into focus four key areas that hold significance in the future of STEM pedagogy, as well as a few remarks on them, as follows:

Innovation and pedagogy are two sides of the same coin. The balance of two parameters should be designed as per the suitability and adaptability of the educators and students. Tailor-made innovations as per the requirement of educators with proper training can go hand in hand in the long run.

Skill development of educators in pedagogy is as important as technological advancements. Our literature survey reveals a deficit in the competence of many teachers in new technology adaptability. E-learning platforms have slowly gained space in classrooms, and one potentially helpful effect of the pandemic has been to force educators to engage with technology and e-learning. The new educator generation will have to be familiar with the technology in order to lead to academic success.

The article attempts to provide a bird's eye view on the possible holistic tools that can serve as a solution for the optimizing and modernization of STEM pedagogy. The flow cycle of the integration process of STEM content leads to innovation in pedagogy in identifying proper parameters that require attention. Skill-set balancing can be a powerful tool for providing a midway solution among students and their teachers. Similarly, high and low matrix analysis in inquiry-based learning can be an innovative solution for better teaching methodology.

The post-pandemic scenario will be transforming very rapidly in pedagogy in general, and particularly in STEM education. The pandemic will leave long lasting imprints on both students and educators. The PESTLE analysis and the conditional matrix could be powerful tools in developing the new pedagogy policy and frameworks. The future is challenging for the overall education sector, but proper analysis can generate innovative ideas. The pandemic can also be a wake-up call for disruption in existing pedagogy models and incentives to look for new answers.

The review also suggests the challenge lies in modernizing the approach, as new platforms are complicated. The solution lies with pedagogy itself, as educators with adequate content knowledge must learn to merge their expertise with modern e-learning platforms. STEM pedagogy will see transformation only if the old, well-defined concepts of content knowledge shake hands with the novel modules. This gap needs STEM researchers' deliberate attention, as the more this gap widens, the more challenging the task will become for educators. 
Author Contributions: Conceptualization, C.D. and B.K.; methodology, I.S.; validation, C.D., B.K. and G.N.; formal analysis, C.D.; investigation, B.K.; resources, S.S.; data curation, G.N.; writing-original draft preparation, B.K.; writing-review and editing, C.D.; visualization, B.K.; supervision, I.S.; project administration, C.D.; funding acquisition, C.D. All authors have read and agreed to the published version of the manuscript.

Funding: This research was funded by EUROPEAN COMISSION ERASMUS+ PROGRAMME, grant number Project reference: 612898-EPP-1-2019-1-FI-EPPKA3 and The APC was funded by ArtIST PROJECT.

Institutional Review Board Statement: Not applicable.

Informed Consent Statement: Not applicable.

Data Availability Statement: Not applicable.

Conflicts of Interest: The authors declare no conflict of interest.

\section{References}

1. Kennedy, T.J.; Odell, M.R.L. Engaging Students In STEM Education. Sci. Educ. Int. 2014, 25, 246-258.

2. Basri, W.S.; Alandejani, J.A.; Almadani, F.M. ICT Adoption Impact on Students' Academic Performance: Evidence from Saudi Universities. Educ. Res. Int. 2018, 2018. [CrossRef]

3. Nadelson, L.S.; Seifert, A.; Moll, A.J.; Coats, B. An Integrated Approach to Teacher Professional Development in STEM. J. STEM Educ. 2012, 13, 69-84.

4. Li, Y.; Wang, K.; Xiao, Y.; Froyd, J.E. Research and trends in STEM education: A systematic review of journal publications. Int. J. STEM Educ. 2020, 7. [CrossRef]

5. Cairns, D.; Areepattamannil, S. Exploring the Relations of Inquiry-Based Teaching to Science Achievement and Dispositions in 54 Countries. Res. Sci. Educ. 2019, 49. [CrossRef]

6. Drummond, A.; Sweeney, T. Can an objective measure of technological pedagogical content knowledge (TPACK) supplement existing TPACK measures? Br. J. Educ. Technol. 2017, 48, 928-939. [CrossRef]

7. Damsa, C.; Jornet, A. Revisiting learning in higher education-Framing notions redefined through an ecological perspective. 2016. Frontline Learn. Res. 2016, 4, 39-47. [CrossRef]

8. Aalto, E.; Tarnanen, M.; Heikkinen, H.L.T. Constructing a pedagogical practice across disciplines in pre-service teacher education. Teach. Teach. Educ. 2019, 85, 69-80. [CrossRef]

9. Liu, Z.Y.; Chubarkova, E.; Kharakhordina, M. Online technologies in STEM education. Int. J. Emerg. Technol. Learn. 2020, 15, 20-32. [CrossRef]

10. Chien, Y.-H.; Chu, P.-Y. The Different Learning Outcomes of High School and College Students on a 3D-Printing STEAM Engineering Design Curriculum. Int. J. Sci. Math. Educ. 2018, 16, 1047-1064. [CrossRef]

11. Hesser, T.L.; Schwartz, P.M. iPads in the Science Laboratory: Experience in Designing and Implementing a Paperless Chemistry Laboratory Course. J. STEM Educ. 2013, 14, 5-9.

12. Maniu, C.S.; Sandou, G.; Letort-Le Chevalier, V. Feedback on Innovative Pedagogy for teaching Systems Modeling. IFACPapersOnLine 2019, 52, 260-265. [CrossRef]

13. Mulqueeny, K.; Kostyuk, V.; Baker, R.S.; Ocumpaugh, J. Incorporating effective e-learning principles to improve student engagement in middle-school mathematics. Int. J. STEM Educ. 2015, 2, 15. [CrossRef]

14. Beumann, S.; Wegner, S.-A. An outlook on self-assessment of homework assignments in higher mathematics education. Int. J. STEM Educ. 2018, 5, 55. [CrossRef] [PubMed]

15. Wongnaa, C.A.; Boachie, W.K. Perception and adoption of competency-based training by academics in Ghana. Int. J. STEM Educ. 2018, 5, 52. [CrossRef]

16. Gamage, S.H.P.W.; Ayres, J.R.; Behrend, M.B.; Smith, E.J. Optimising Moodle quizzes for online assessments. Int. J. STEM Educ. 2019, 6, 27. [CrossRef]

17. Kelley, T.R.; Knowles, J.G. A conceptual framework for integrated STEM education. Int. J. STEM Educ. 2016, 3. [CrossRef]

18. English, L.D. STEM education K-12: Perspectives on integration. Int. J. STEM Educ. 2016, 3, 3. [CrossRef]

19. Holmlund, T.D.; Lesseig, K.; Slavit, D. Making sense of "STEM education" in K-12 contexts. Int. J. STEM Educ. 2018, 5, 32. [CrossRef] [PubMed]

20. Top, L.M.; Schoonraad, S.A.; Otero, V.K. Development of pedagogical knowledge among learning assistants. Int. J. STEM Educ. 2018, 5, 1. [CrossRef]

21. Vongkulluksn, V.W.; Matewos, A.M.; Sinatra, G.M.; Marsh, J.A. Motivational factors in makerspaces: A mixed methods study of elementary school students' situational interest, self-efficacy, and achievement emotions. Int. J. STEM Educ. 2018, 5, 43. [CrossRef]

22. Miller, T. Developing numeracy skills using interactive technology in a play-based learning environment. Int. J. STEM Educ. 2018, 5, 39. [CrossRef] 
23. Graesser, A.C.; Hu, X.; Nye, B.D.; VanLehn, K.; Kumar, R.; Heffernan, C.; Heffernan, N.; Woolf, B.; Olney, A.M.; Rus, V.; et al. ElectronixTutor: An intelligent tutoring system with multiple learning resources for electronics. Int. J. STEM Educ. $2018,5,15$. [CrossRef]

24. Nye, B.D.; Pavlik, P.I.; Windsor, A.; Olney, A.M.; Hajeer, M.; Hu, X. SKOPE-IT (Shareable Knowledge Objects as Portable Intelligent Tutors): Overlaying natural language tutoring on an adaptive learning system for mathematics. Int. J. STEM Educ. 2018, 5, 12. [CrossRef]

25. Gardner, M.; Tillotson, J.W. Interpreting Integrated STEM: Sustaining Pedagogical Innovation Within a Public Middle School Context. Int. J. Sci. Math. Educ. 2019, 17, 1283-1300. [CrossRef]

26. Scott-Parker, B.; Barone-Nugent, E. Enlightening Stem Engagement during High School—Make It Real Banana Peel. J. STEM Educ. Innov. Res. 2019, 20, 5.

27. Achat-Mendes, C.; Anfuso, C.; Johnson, C.; Shepler, B.; Hurst-Kennedy, J.; Pinzon, K.; Simmons, R.; Dekhane, S.; Savage, J.; Sudduth, E.; et al. Learning, Leaders, and STEM Skills: Adaptation of the Supplemental Instruction Model to Improve STEM Success and Build Transferable Skills in Undergraduate Courses and Beyond. J. STEM Educ. Innov. Res. 2019, $20,14$.

28. National Research Council; National Academy of Engineering. STEM Integration in K-12 Education: Status, Prospects, and an Agenda for Research; Honey, M., Pearson, G., Schweingruber, H., Eds.; The National Academies Press: Washington, DC, USA, 2014; ISBN 978-0-309-29796-7.

29. Sorby, S.; Veurink, N.; Streiner, S. Does spatial skills instruction improve STEM outcomes? The answer is 'yes.' Learn. Individ. Differ. 2018, 67, 209-222. [CrossRef]

30. Kirsch, C. Opening minds to translanguaging pedagogies. System 2020, 92, 102271. [CrossRef]

31. Shepard-Carey, L. Making sense of comprehension practices and pedagogies in multimodal ways: A second-grade emergent bilingual's sensemaking during small-group reading. Linguist. Educ. 2020, 55, 100777. [CrossRef]

32. Hanley, P.; Thompson, R. 'Generic pedagogy is not enough': Teacher educators and subject-specialist pedagogy in the Further Education and Skills sector in England. Teach. Teach. Educ. 2021, 98, 103233. [CrossRef]

33. Dasgupta, C.; Magana, A.J.; Vieira, C. Investigating the affordances of a CAD enabled learning environment for promoting integrated STEM learning. Comput. Educ. 2019, 129, 122-142. [CrossRef]

34. Gibson, A.; Siopsis, M.; Beale, K. Improving Persistence of STEM Majors at a Liberal Arts College: Evaluation of the Scots Science Scholars Program. J. STEM Educ. Innov. Res. 2019, 20, 6-13.

35. Stull, A.T.; Fiorella, L.; Gainer, M.J.; Mayer, R.E. Using transparent whiteboards to boost learning from online STEM lectures. Comput. Educ. 2018, 120, 146-159. [CrossRef]

36. Cerda-Diaz, L. Assessment in TIC Skills in Pedagogy Students of the Catholic University of Maule (Chile). Procedia Soc. Behav. Sci. 2017, 237, 893-899. [CrossRef]

37. Kong, S.C. An experience of a three-year study on the development of critical thinking skills in flipped secondary classrooms with pedagogical and technological support. Comput. Educ. 2015, 89, 16-31. [CrossRef]

38. Aladé, F.; Lauricella, A.R.; Beaudoin-Ryan, L.; Wartella, E. Measuring with Murray: Touchscreen technology and preschoolers' STEM learning. Comput. Human Behav. 2016, 62, 433-441. [CrossRef]

39. Chi, H.; Jain, H. Teaching computing to STEM students via visualization tools. Procedia Comput. Sci. 2011, 4, 1937-1943. [CrossRef]

40. Caglar, F.; Shekhar, S.; Gokhale, A.; Basu, S.; Rafi, T.; Kinnebrew, J.; Biswas, G. Cloud-hosted simulation-as-a-service for high school STEM education. Simul. Model. Pract. Theory 2015, 58, 255-273. [CrossRef]

41. De Jong, T.; Sotiriou, S.; Gillet, D. Innovations in STEM education: The Go-Lab federation of online labs. Smart Learn. Environ. 2014, 1, 1-16. [CrossRef]

42. Crippen, K.J.; Archambault, L. Scaffolded Inquiry-Based Instruction with Technology: A Signature Pedagogy for STEM Education. Comput. Sch. 2012, 29, 157-173. [CrossRef]

43. van der Graaf, J.; Segers, E.; de Jong, T. Fostering integration of informational texts and virtual labs during inquiry-based learning. Contemp. Educ. Psychol. 2020, 62, 101890. [CrossRef]

44. Liu, C.; Bano, M.; Zowghi, D.; Kearney, M. Analysing user reviews of inquiry-based learning apps in science education. Comput. Educ. 2021, 164, 104119. [CrossRef]

45. Newton, X.A.; Tonelli, E.P. Building undergraduate STEM majors' capacity for delivering inquiry-based mathematics and science lessons: An exploratory evaluation study. Stud. Educ. Eval. 2020, 64, 100833. [CrossRef]

46. Al Mamun, M.A.; Lawrie, G.; Wright, T. Instructional design of scaffolded online learning modules for self-directed and inquiry-based learning environments. Comput. Educ. 2020, 144, 103695. [CrossRef]

47. Zhu, G.; Xing, W.; Popov, V. Uncovering the sequential patterns in transformative and non-transformative discourse during collaborative inquiry learning. Internet High. Educ. 2019, 41, 51-61. [CrossRef]

48. Chang, C.; Chang, C.K.; Shih, J.L. Motivational strategies in a mobile inquiry-based language learning setting. System 2016, 59, 100-115. [CrossRef]

49. Blevins, B.; Magill, K.; Salinas, C. Critical historical inquiry: The intersection of ideological clarity and pedagogical content knowledge. J. Soc. Stud. Res. 2020, 44, 35-50. [CrossRef]

50. Thuneberg, H.M.; Salmi, H.S.; Bogner, F.X. How creativity, autonomy and visual reasoning contribute to cognitive learning in a STEAM hands-on inquiry-based math module. Think. Ski. Creat. 2018, 29, 153-160. [CrossRef] 
51. Oyedotun, T.D. Sudden change of pedagogy in education driven by COVID-19: Perspectives and evaluation from a developing country. Res. Glob. 2020, 2, 100029. [CrossRef]

52. Palacio-ortiz, J.D.; Londoño-herrera, J.P.; Robledo-rengifo, P.; Patricia, C. pandemic Jo ur 1 P re of. Rev. Colomb. Psiquiatr. 2020, 102560. [CrossRef]

53. Stoller, J.K. A Perspective on the Educational "SWOT" of the Coronavirus Pandemic. Chest 2021. [CrossRef] [PubMed]

54. Voogt, J.; Fisser, P.; Pareja Roblin, N.; Tondeur, J.; van Braak, J. Technological pedagogical content knowledge-A review of the literature. J. Comput. Assist. Learn. 2013, 29, 109-121. [CrossRef]

55. Christopher, E.; Edmund, A.; Ian, L. Hip-hop based interventions as pedagogy/therapy in STEM: A model from urban science education. J. Multicult. Educ. 2016, 10, 307-321. [CrossRef] 